\title{
Decolonising Teacher Education Curriculum in South African Higher Education
}

\author{
Oluwatoyin A. Ajani ${ }^{1} \&$ Bongani T. Gamede 2 \\ ${ }^{1}$ Edu-HRight Research Unit, North-West University, Potchefstroom, South Africa \\ ${ }^{2}$ Department of Social Sciences Education, University of Zululand, South Africa \\ Correspondence: Oluwatoyin A. Ajani, Edu-HRight Research Unit, North-West University, Potchefstroom, South \\ Africa.
}

Received: December 28, 2020

Accepted: May 5, 2021

Online Published: May 6, 2021

doi:10.5430/ijhe.v10n5p121

URL: https://doi.org/10.5430/ijhe.v10n5p121

\begin{abstract}
Calls for the decolonisation of higher education in South Africa gained prominence after the \#Rhodesmustfall, \#Feesmustfall and series of 2015-2016 students' protests in South African higher institutions. Visible in the demands of the students during these protests was the need for the decolonisation of higher education curriculum to ensure reflection of diverse realities in South Africa. This led to various conferences in different parts of the Republic. However, while some scholars are clamouring for the need for decolonisation, others consider the desire for decoloniality and glocalization. Thus, the subject of decolonisation remains a debate in South African society. Meanwhile, decolonisation is still very much crucial. Seemingly, in the words of Steve Biko, decolonization should begin from the mind. Hence, this discursive study explores how pre-service teachers' minds can be decolonised for realities in transforming South African higher education. The study adopts Critical Race Theory as a lens for this phenomenon. South African higher education curriculum has predominantly been Eurocentric and epistemic, reflecting Western dominance in post-apartheid South Africa. The study argues why and how South African higher education institutions can place teacher education at the centre of learning experiences, for students to adapt and maximize the realities in their contexts, and for responsive lived experiences. Thus, adding voices to a curriculum that promotes total rethink, reflections and reconstruction of students' minds in integrating the existing Eurocentrism and epistemic knowledge with African philosophy in higher education institutions.
\end{abstract}

Keywords: decolonising, transformation, realities, Africanisation, learning experiences, Eurocentrism, decolonisation

\section{Background to the Study}

South African higher education is diversely complex in context; it is characterised by various challenges and limitations, some of which are: inequalities, inadequate resources and complicated curriculum (Fomunyam \& Teferra, 2017; Tuck \& Yang, 2012; Ajani, 2019). The 2015 “\#RhodesMustFall”, "FeesMustFall” and other students' protests that rocked South African higher institutions gave prominence to the calls for decolonising academic curricula by the students. The students agitated for learning experiences that are critically African discourses (Murris, 2016; Ajani, 2019). This has strengthened the student movements and others to advance the calls for decolonising the curricular for higher education in South Africa. Jansen (2017) opines that decolonising higher education has been so intensified with emphasis on the decolonised curriculum for higher education; therefore, the need to decolonise students' minds will be significant to South African higher institutions. According to Sayed, Motala, and Hoffman (2017:1), "decolonising the curricula has recently been re-energised by the students through political action across South Africa."

Seemingly, Naicker (2016) opines that decolonising university curricula and academic culture will lead to desired social transformation at the institutions. Shay (2016) opines that South African higher education is significantly challenged by academic curricula that do not address the realities of the diverse contexts in South African students. The aftermath of \#RhodesMustFall was the mid-October 2015 'Transformation summit' convened by the Ministry of Higher Education and Training to address the students' demands (Davids, 2016). However, "the summit was unable to offer solutions to the students' agitation" (Badat, 2016:13). The failure of this summit to attend to the needs of the students provoked increasingly large scale protests marked with violent clashes between the students and the police in some universities, and also at the Parliament. The protests led to wanton destructions of university properties, loss of lives and subsequent arrest of some students. Mheta, Lungu, and Govender (2018) highlight that the university crisis 
has indicated how racial discrimination and colonialism permeate South African public life. These large student protests rekindled decolonising the curricula in the universities among other things (Nzimande, 2015; Badat, 2016; Pilane, 2016). Hence, the struggle for decolonising university curricula has been rife in South Africa. According to Mama (2015), Pillay (2015), and Sayed et al (2017), the similar struggle was prevalent in some other African countries and were thus described as intellectual struggles. These intellectual struggles traced back to several years ago in many African countries included demands for Africanisation and indigenisation of knowledge by Edward Blyden in Liberia (Blyden, 1872); Ahmadu Bello University in Nigeria (Mustapha, 1995); the University of Ibadan, Nigeria (Ake, 1982); Dar es Salaam, Tanzania (Shivji, 1993); Makerere, Uganda (Mamdani, 1990) and Cheikh Anta Diop, Senegal (Bathily, Diouf \& Mbodj, 1995).

Decolonising higher education is to rediscover and decolonise the existing bodies of knowledge that have become unchanging and unchangeable learning experiences and institutions (Sayed et al., 2017). According to Mheta, Lungu and Govender (2018), decolonising teacher education is long overdue in South African universities due to the Eurocentric curricula being operated in the universities. It is therefore imperative for South African academics and students to develop the capacity to theorise their own conditions in complex relations to others (outside world) for their own realities as learning experiences. Seemingly, Jansen (2017), Le Grange (2016), Le Grange (2018), Venter (2018), Mbembe (2015) and CHE (2017) argue that the process of decolonising teacher education is multi-complex and complicated as well. Therefore, decolonising teacher education to reflect South African diverse contexts, is a process of clarification and understanding de-racialisation, Africanisation, Eurocentrism, Westernisation, Colonialism, and Coloniality which are key complex concepts that can influence decolonising education (Maldonado-Torres, 2006, 2007; Mbembe, 2015; Le Grange, 2016; CHE, 2017; Jansen, 2017; Le Grange, 2018; Venter, 2018).

Reflections on decolonising teacher education curricula imply that teacher education needs to be contextualised within this frame of thinking. In Jansen's (2017) views, he suggests six approaches to decolonising higher education, which can be applied to decolonising teacher education. These approaches are: decolonising through addictive-inclusive knowledge; decentralisation of European knowledge; critical engagement of curriculum with settled knowledge, repatriation and linking of occupied knowledge to the society; Africanisation of curriculum contents; and decolonising the curriculum for encounters with entangled knowledge. Integration of these six conceptions into decolonising teacher education implies the deconstruction of curriculum contents for teacher education to prepare pre-service teachers for realities in South African contexts. Decolonising teacher education can promote the possibilities of decolonising education to understand ourselves through decolonised knowledge (Jansen, 2017). Therefore, this phenomenological study reflects on the possibilities of decolonising teacher education in South African universities.

\section{Decolonisation as a Concept}

Decolonisation is not a new phenomenon in Africa. As mentioned earlier, different steps of decolonisation have been noted in different parts of Africa. These include Africanisation and indigenisation of knowledge by Edward Blyden in Liberia (Blyden, 1872); Ahmadu Bello University in Nigeria (Mustapha, 1995); the University of Ibadan, Nigeria (Ake, 1982); Dar es Salaam, Tanzania (Shivji, 1993); Makerere, Uganda (Mamdani, 1990) and Cheikh Anta Diop, Senegal (Bathily, Diouf \& Mbodj, 1995). Years after South African democracy, calls to decolonise higher education have continued to be intensified (Kapoor, 2007). According to Fomunyam (2017) and Ajani (2019), decolonisation is an attempt to restructure academic curricula to reflect a people's mental and psychological prowess. "Who they are, where they come from and where they are going to is to be showcased" (Fomunyam, 2017:6799).

Conversely, Santos (2014) opines that there is a need for teacher education to be situated within the Africanisation of the curricula and should be detached from forefront colonial and apartheid histories. Hence, the South African higher education contexts deserve dismantled Eurocentric epistemologies that framed teacher education (Mheta et al, 2018), and inclusion of the indigenous knowledges in learning experiences. Correspondingly, Le Grange (2016) posits that the Africanisation of teacher education is critical to the transformation of academic curricula of South African universities. Seemingly, Mbembe (2015) observes that 21 years after the democratic government in South Africa, decolonising the teacher education remains a significant approach to rediscover and recover the realities that need to be taught in dismantling unresolved colonial and apartheid legacies that exist in universities' knowledge production and curricula. Teacher education has been dominated by prolonged uncertainties, contradictions, conflicts and call for the need to decolonise the universities (Mbembe, 2015).

Sanford, Williams, Hopper and McGregor (2012) assert that teacher education is globally being reviewed regularly to empower pre-service teachers with foundational fundamental philosophies which are yet to be fully attained. Sanford et al (2012) argue for decolonised curricula that will present flexible learning experiences and make teachers agent of changes for realities in schools and learners, and voices in teacher education. Decolonising teacher education follows 
a complicated systemic process. This according to Poka Laenui (2000), Chilisa (2012) are in five phases to achieve: rediscovery and recovery; mourning; dreaming; commitment and action. Rediscovery and recovery enable the colonised minds to rediscover and recover their own entities, historic backgrounds, cultural backgrounds, diverse languages and peculiar identities. The mourning stage is the phase at which they lament on the continuity of coloniality and the need for social realities. This is critical to heal and further lead the people to dreaming. The process of dreaming is for the colonised minds to place their histories within worldviews, and utilize their indigenous knowledge systems to theorise alternative possibilities - known as decolonised curriculum. Commitment is the stage at which academics/students advance the decolonised voices in the university curriculum to demonstrate commitment. The last in the process is the action stage where the various dreams and commitments are translated into viable strategies that can be adopted for social transformation. Hence, the transformation of teacher education curriculum can be done to attain broader and societal transformation.

Similarly, Smith (1999) highlights some elements of decolonisation, which are self-determination, deconstruction and reconstruction; internationalisation of indigenous experiences and social justice; ethics, language, historical relics and critique. Deconstruction and reconstruction focuses on how to discard the wrong perceptions or information, and 'interrogating distortions of people's life experiences, negative labelling, deficit theorizing, genetically deficient or culturally deficient models that pathologized the colonised ... and retelling the stories of the past and envisioning the future' (Chilisa 2012: 17). In the words of Le Grange (2016:3), "Self-determination and social justice relate to the struggle by those who have been marginalised by the Western academy and about seeking legitimacy for knowledge that is embedded in their own histories, experiences and ways of viewing reality. Ethics relates to the formulation, legislation and dissemination of ethical issues related to the protection of indigenous knowledge systems". Language is concerned with the significance of indigenous language in teaching/learning to dismantle the anti-imperialist struggle. Internationalization of indigenous learning experiences by various international scholars in knowledge production of lived experiences, critical issues and significant struggles of the colonised minds using global and local spaces to share. Historical knowledge of the colonised is an attempt to discover and recover the historical, cultural relics as well as the languages of the colonised people from the past to the present. Existing knowledge "continues to deny the colonised and historically marginalised other space to communicate from their own frames of reference" (Chilisa 2012: 19).

Prominent voices continue to strengthen the calls for decolonisation in South Africa (Ndlovu-Gatsheni, 2013; Disemelo, 2015; Ajani, 2019; Ndlovu-Gatsheni \& Omanga, 2020). It is an ardent response to long existed colonialism, neo-colonialism and of recent, (re)ascendency of neoliberalism in South Africa. Conversely, Odora-Hoppers and Richards (2011, Jansen, 2017) report that first-generation colonialism succeeded the physical conquer of spaces and bodies of the colonised people, and the colonisation of the second generation was done through the colonisation of the learners' minds through various fields, such as education, economics, law, and science. Neo-colonialism according to Kwame Nkrumah, the first President of Ghana, avers that despite the independence of Ghana; the country still remains under the influence of ex-colonial masters or the emerging superpowers. The emerging superpowers refer to those countries or bodies influencing the economic, political or social systems of the colonised countries. These include multinational corporations, international monetary organisations, educational and cultural institutions (Ashcroft, Griffiths \& Triffin 2000). Furthermore, Kwame Nkrumah posits that neo-colonialism is complicated and carefully hidden to discover. New-elites from the colonised countries are used to perpetrate colonialists' ideas and objectives even after post-independence. The recent effort on (re)ascendency of neoliberalism in various South African universities is to rediscover the institutions. In the words of Peters (2007), he describes these universities as neo-liberal universities. Seemingly, Olssen, Codd and O'Neill (2004) assert that there are three features of neoliberals - a total commitment to the liberty of individuals and absolute reduction of the state; a change in policy and systemic ideology against government intervention; and a general belief that allows self-regulating market forces. The recent uprising in the call for neo-liberal political movements is propelled by the need to provide citizens with adequate basic needs as well as regulations of service delivery.

Studies affirm that the first and second generation colonialism succeeded in the relegation of cogent indigenous knowledges (Le Grange, 2016). In the words of Santos (2014: 92), neglect of knowledge is known as 'the murder of knowledge' which he describes as epistemicide. Furthermore, Santos (2014:92) asserts that "unequal exchanges among cultures have always implied the death of the knowledge of the subordinated culture, hence the death of the social groups that possessed it. In most extreme cases, such as that of European expansion, epistemicide was one of the conditions of genocide. The loss of epistemological confidence that currently afflicts modern science has facilitated the identification of the scope and gravity of the epistemicides perpetrated by hegemonic Eurocentric modernity". This implies that only what gives cognitive justice as epistemicide should be encouraged. Eurocentric or 
Western knowledge is the core of South African universities' curricula from inception. These academic curricula exclusively exclude indigenous knowledge of the colonised people of South Africa. In the words of Le Grange (2016), he describes the curricula as the colonial model of academic, routed in Western knowledge right from the apartheid era and even in the post-apartheid and democratic period. However, Le Grange (2016) reports a significant change in student demographic while staff demographics remain unchanged in historically white-dominated universities in South Africa. Though, he affirms that neo-colonialism continue to exist in these universities.

Le Grange (2016) posits that unchanged staff demographics in historically White-dominated universities is to further ensure that colonial academic structure is preserved. This supports Nkrumah's assertion that the preservation of colonial academic structures is perpetrated under the disguise of academic freedom and institutional autonomy. South African universities are significantly influenced by the involvement, grants and support from superpowers through the state economy. Most public universities are state-aided universities rather than being state-funded universities. This implies why student fees and other charges have been rising and propelled students' protests of 2016-2016 in South African universities. The students demanded decolonisation of the curriculum as one of their protests' demands. It is therefore imperative to decolonise teacher education in South African universities to accede to the demand and to reposition the sector. The decolonising teacher education curriculum is a long term process that will be challenging. According to Guattari (2001), it will be difficult to create absolute new ways of life but we can adopt new possibilities of responding to issues. Pindar and Sutton (2001) are of the opinion that changing one's ways of living depends on how one responds to issues as new references. This implies that actions are not to be pre-determined but to be activated according to situations. Responding to issues as they unfold is the reality of the society, where indigenous knowledge is applied to solve societal problems.

Furthermore, Nkrumah (1974), Dei (2000), Mbembe $(2015,2016)$ concur that indigenous knowledge does not exist without the influences of other knowledges. Their argument is for the bodies of knowledge to influence each other continually in knowledge production. This provides a knitted dichotomy between Indigenous and Western knowledges (Dei 2000). Dei (2000) and Ajani (2019) opine that there is however the need to challenge imperial ideologies and colonial knowledge production which continually dominate academic curricula. The exclusion of indigenous knowledges from the universities makes the (re)colonisation of knowledges and cultures in local South African contexts to be difficult (Dei 2000; Mignolo, 2011; Mbembe, 2016; Ajani, 2019; Ndlovu-Gatshen \& Omanga, 2020).

Decolonising the teacher education curriculum is not an easy task but needs to follow a process where indigenous knowledge, skills and African philosophy should be integrated into the decolonised curriculum for teacher education.

\subsection{Theoretical Framework}

This study builds on how teacher education can be used as an intellectual space for decolonising education in South African universities. Learning spaces are where students' minds are colonised and can be made to reflect the expectations of the dominant knowledge (Nkrumah, 1974; Ngugi, 1986; Maldonado-Torres, 2007; Grosfoguel, 2007, 2011; Ajani, 2019).

The study is underpinned by critical race theory (DeCuir \& Dickson, 2004). According to the extant literature, the critical race theory (CRT) is significant to theorise decolonising and transformation of teacher education curriculum as it focuses on the significance of every race in the construction of its knowledge in relations to diverse groups (Roithmayer, 1999; DeCuir \& Dickson, 2004; Hiraldo, 2010). CRT is a revolutionary movement that puts race at the centre of critical analysis (Roithmayer, 1999). According to DeCuir and Dickson (2004), CRT enables education institutions that are dominated by racist pedagogical practices, racism, as well as Eurocentric epistemologies in their existence to be dismantled to accommodate diverse groups (McCoy \& Rodricks, 2015). CRT as a theory was developed in the 1970s to dismantle various systems that disadvantaged some groups in the United States of America and to promote the 'reversal of civil rights advances' (Hiraldo, 2010:3); this was later extended to education in 1995 (Ladson-Billings \& Tate, 1995) as a social construct to challenge the existing oppression in the education system between the black and white students; thus, theorising education injustice (DeCuir \& Dickson, 2004; Hiraldo, 2010). CRT in this phenomenon understands the diverse voices on decolonising teacher education curriculum.

Accordingly, DeCuir and Dixson (2004), argue that the main focus of CRT is to promote the deep structure as well as the systemic change for social justice in higher education. Its application to decolonising teacher education curriculum implies that decolonising teacher education will shape South African higher education landscape. CRT is highly significant to the transformation of social structures and advancing the political commitment of racial emancipation in higher education (Roithmayer, 1999). 
Decolonising the curriculum in the contexts of South African teacher education is controversial and complicated with several discordant voices (Fomunyam \& Teferra, 2017). According to Mgqwashu (2016) and Fomunyam (2017), the contextualisation of indigenous knowledge and experiences shift away from teacher education from being dominated with Eurocentric or global north experiences as learning experiences, which are in existence for ages. In the words of Le Grange (2016), decolonising the generational colonised people's physical spaces, and minds is necessary for teacher education. Furthermore, decolonising the mind through diverse curricula in various academic disciplines which include education, science, economics and laws are necessary for decolonising higher education (Le Grange, 2016). The minds have been in knowledge, ideas, values and skills colonialism through Western learning experiences "which were violence, economic exploitation, disfigurement of African communities and culture in development and modernisation" (Luckett, 2016: 416-417).

This aligns with Fanon's (2008) views in his book, "Black skin, white masks" where he affirms the need to decolonise the students' minds based on "the juxtaposition of the black and white races" to dismantle Eurocentric learning experiences as opined by CRT to liberate the black students. In other words, Fanon believes in the necessity to overcome the existing effects of academic colonialism on black students. Thus, this concurs with CRT in decolonising teacher education by providing appropriate learning experiences that accommodate interrelationship with others in real everyday lives.

Fomunyam (2014) is of the opinion that a curriculum as a series of potential experiences should allow students to critique their thinking and acting. Hence, the need for the decolonising teacher education curriculum is an attempt to strengthen teacher education in higher education. Scholars affirm that "Western, Colonial and Eurocentric knowledge is normatively and universally contrary to the existing indigenous local knowledge" (Mahabeer, 2018:10). Conversely, Andreotti, Ahenakew and Copper (2011) in agreement with the views of Mbembe (2015), avow that decolonising this form of existing knowledge and the curriculum in South African universities, diverge learning from the hegemonic, oppressive and suppressive Eurocentric curricula are critical. However, in the bid to dispose of colonial and discriminatory legacies, eradication of inequalities in knowledge production proves to be difficult (Heleta, 2016; McKaiser, 2016).

Therefore, decolonising teacher education curriculum will give relevance to diverse communities' social and historical realities (Mbembe, 2015; Ramrathan, 2016), where rethinking university curriculum is the possibilities for decolonising the teacher education curriculum in South Africa (Le Grange, 2014; 2016). According to Leibowitz (2012), teacher education curriculum should dwell on students' immediate environments for relevant and significant everyday lived experiences. Learning experiences should come from the students' immediate environments to aid learning experiences. Also, teacher education, as part of the higher education is an avenue to drive South African economic development as well as the development of good and diversifying citizenship (Department of Higher Education and Training (DHET) (National Planning Commission, 2011; De Wet \& Simmonds, 2019).

Conversely, decolonising the teacher education as a phenomenon will be used to contextualise the teacher education in the higher institutions, using the contextualised contents in the decolonised curriculum in preparation for pre-service teachers. This will enhance the sharing of knowledge, impartation of skills and moulding of attitudes that respect individual human rights, fundamental freedoms, tolerance, equality and peace, among individuals (Zembylas, 2018).

It is the transformative responsibility of teacher education in South Africa to enhance the public good, where pre-service teachers will be empowered to facilitate moral and ethical disposition in school learners (Leibowitz, 2012). Thus, the rationale for the adoption of CRT as a theoretical framework is to promote a deeper and clear understanding of the need to reconstruct learning experiences in consideration of the realities of students' environments (Decuir \& Dixson, 2004). Furthermore, this rediscovers learning experiences for reconceptualization with significant emphasis on the realities of students' social identities (Pinar,1975; 2011) to decolonise their minds based on social identities (Fanon, 2008). Thus, the adoption of CRT into decolonising teacher education curriculum in South Africa is for the integration and contextualisation of students' realities into curriculum designs for pre-service teachers. The integration enables the students to relate their learning experiences to their immediate environment. This allows them to be creative in knowledge creation and facilitation when they finally graduate from the teacher training process.

\subsection{Decolonising Teacher Education Curriculum}

According to Pinar (2011), curriculum as currere which is translated 'to run the course'. Pinar $(2004 ; 2011)$ posits curriculum as an active conceptual force where newness, creation of things unforeseen, experimentation, expanding of differences and movement to open up curriculum for multiple ways of pedagogical lives. This is the basis for the 
decolonising curriculum for teacher education. The word 'curriculum' in the context of higher education was first used to relate to school education. It was further used by Frank Taylor (1911) as a dominant idea in higher institutions across the globe to model education. Gough (2011:3) asserts that curriculum as a model developed by Taylor places influences on crafting systems that follow specified objectives-driven curriculum models as developed by Franklin Bobbitt $(1918,1928)$ and Ralph Tyler (1949). According to the outcomes-based approaches of Bobbitt and Tyler, the curriculum is a simple system that aims at providing students with learning experiences that can be assessed to determine students' achievements.

The curriculum can also be described as the learning experiences that students are exposed to about the past, present and future (Grumet, 1981). This implies that the curriculum provides the students with opportunities to find out about the past, present and future to attain the intended learning outcomes. Ted Aoki (1999) in his own words, describes the curriculum as what focuses on the planned learning experiences but also on how it is attained by students and their teachers. The curriculum to be attained must take into consideration what the students experience in the teacher education curriculum; this is a basis for decolonising teacher education. Aoki (1999) affirms that the curriculum-as-lived does not change the curriculum-as-plan, but rather strengthened the two as intellectual space for struggle, creativity and transformation. Tyler (1949), Bobbitt (1928) and Pinar (2011) aver that three broad perspectives exist in universities' curriculum which are: the explicit, hidden and null curriculum. The curriculum can be explicit when students are provided with learning experiences in form of module frameworks, assessments guidelines, prescribed readings, etc. The hidden curriculum is the learning experiences that revolve around universities' culture and values. While the null curriculum is the learning experiences that are left out - what students are not taught or learned in universities. The distinctions between the hidden curriculum and the null curriculum of teacher education are what Pinar (2011) describes as the etymological root of the curriculum in his currere'. He places emphasis on the significance of the curriculum on individual experience. Furthermore, Pinar (2011) asserts that currere places priviledges on the individual as individual differences exist in students' genetic makeup, upbringings, races, genders, social class, and so on. Contrastingly, Deleuze and Guattari (1994) posit that currere is a way to approach the world and not what currere is as a concept.

According to Deleuze and Guattari (1994), the description of Neo-liberalism focuses on the paradoxical nature of currere's etymology based on its active and reactive components. This explains why the curriculum is active in its conceptual force with no fixity or closeness to a pedagogical life. Le Grange (2016) posits that it relates to the intrinsic potential of a pedagogical life, where multiple tasks for a pedagogical life. In another related description, Wallin $(2010,2)$ explains 'to run' as viewed by 'currere' to mean the conceptual influence of currere to produce and to create flows, offshoots, guide movements in a system based on the objectives of the intended outcomes. Thus, the conceptual influence currere has, determines and guides newness of knowledge, creation of information in unforeseen situations, learning experimentation, expanding of knowledge differences as well as movements. Decolonising curriculum enables multiple approaches to pedagogical lives to attain the process of decolonisation, where individual differences are recognised and valued for the intrinsic worth. The reactive nature of currere enables colonised knowledge and promotes one way only of knowing as the only way of knowing. This severs alternative ways of knowledge production (Quijano, 2007).

\subsection{Approaches to Decolonising Teacher Education Curriculum}

As indicated earlier, the decolonising curriculum for teacher education is a tricky and complicated one that follows a systematic process. The process is made up of different approaches to attain decolonising the teacher education curriculum. One of the prominent voices in the decolonisation of higher education in South Africa, Le Grange (2016) claims that decolonising teacher education entails liberation of the present curriculum that is epistemic into a fusion of both Ubuntu (I am because we are) and the active force of currere into the oneness of decolonised minds. This recognises the ecological need of curriculum, rather than subjectivity of being individuals. Thus, the decolonised curriculum will evidently promote a shift in subjectivity that makes individuals arrogant of 'I' (Western individualism) to the humble individuals that embrace embedded learning, embodied skills, extended and enacted knowledges that make them fit into the ever-changing world around students.

Decolonising teacher education curriculum through a fusion between Ubuntu-currere approaches implies how we move within the world and vice versa, to potentially create a pedagogical living for us to inhabit the global world. Thus, the oneness of the individual self and his relationship with other human beings as a small microcosm of the entire oneness of self, enables him to be humane towards other human beings and to the larger world around him. The decolonised teacher education curriculum is anchored on the attainment and promotion of the 4Rs, which are critical to a budding Indigenous paradigm. These 4Rs are respectful representation, relational accountability, rights and 
regulation and reciprocal appropriation. The acknowledgement of indigenous knowledges to create intellectual spaces for them in knowledge production is the respectful representation. The connection of every part of the curriculum for accountability in all human relationships is termed relational accountability. The rights and regulation enable all ethical protocols that guide indigenous knowledge ownership to be observed by the world around them (Chilisa, 2012). Reciprocal appropriation asserts that the benefits of various indigenous knowledges are given voices by both universities and communities.

Rediscovery and reformation of academic disciplines of teacher education is another approach to the decolonisation of the curriculum for teacher education (DeCarvalho \& Flórez-Flórez, 2014). According to Le Grange (2014), this entails a radical rethinking of the curriculum for each academic discipline that is Western-dominated. The radical approach to the rethinking of Western knowledge is what Odora-Hoppers and Richards (2011:3) designate as "distant, antiseptic and removed from the experiences of the lived world [that] comes from recognising the pain, anger and anguish being experienced in society". Le Grange (2016:6) posits that "such rethinking requires the expansion of empirical beyond mere observation and listening, to include knowing through the tastes, pain, and hunger of our bodies and expressions of anger, passion and desire". Le Grange (2016) also asserts that another approach from the mourning and healing phase of decolonisation is the integration of emerging trans disciplinary learning experiences that are not socially based knowledge system with that of Indigenous communities of the universities. Seemingly, another approach could be an exploration of local and regional concepts into curricula to dismantle absolute Western epistemologies and to accommodate local contents. An example of this exploration is the presentation of knowledge in sociology of science which emphasises the active aspect of knowledge (Turnbull 1997; Le Grange 2007; Mama, 2015). Attempt to focus on the indigenous knowledge is not to destroy Western knowledge but to recognise indigenous knowledge as third spaces in between Western knowledges for the equitable function of knowledge production in teacher education. Thereby promoting verification of the knowledge production empirical based on the trust of social organisations.

Teacher education in the South African context, calls for pre-service teachers to be groomed together, learn together and share knowledge to promote and preserve human histories as well as epistemologies of human beings from the Cradle known as Afrikology (Nabudere, 2011). Afrikology in his words (Nabudere, 2011) is an attempt by Africans to strengthen their achievements on humanity and to discourage dehumanization acts inherited from Western civilization. It is evident that human knowledge was first created and later disbursed to other parts of the world from Greece and modern Europe, and was later returned to the cradle to fine-tune the experience (Nabudere, 2011). This, re-assert the fact that the original knowledge production started with the Greeks and was copied by the Europeans scholars who succeeded in redesigning and 'methodising' the knowledge into "senseless abstraction and fragmentation" (Nabudere, 2011:7).

According to De Carvalho and Florez-Florez (2014) as interpreted by Le Grange (2016), an inspiration from a university in Ecuador's approach on the decolonising curriculum to accommodate indigenous peoples and their cultures, paved the way for three cycles in the decolonised curriculum, these cycles are the ancestral sciences' formation (community learning); learning of Western sciences (learning to un-learn and re-learn); learning of interculturality (learning to un-learn, re-learn and moving to active learning). This approach is encouraged for adoption in the decolonising curriculum in South African universities by Le Grange (2016).

\section{Conclusion}

In conclusion, this discursive study has shed light on decolonisation as a concept in the South African context and how it can be applied to teacher education, which as discussed is critical to decolonised higher education. The study, however, has added to prominent voices on decolonisation of teacher education by opening up diverse ways of (re)thinking the teacher education curricula and approaches to enhance the decolonising teacher education curriculum. Decolonisation of higher education is a contentious topic that requires further debates and more prominent voices from South African scholars. It is believed that this study will propel more discursive discursions on the phenomenon in an attempt to decolonised teacher education. As highlighted in the study, it is a long and complicated process. This study hopes to spur the scholars in teacher education into more in-depth discussions that will one day culminate into realised decolonisation in higher education curricula.

\section{Acknowledgement}

The researchers appreciate the support of the North-West University and the University of Zululand, South Africa.

\section{References}

Ajani, O. A. (2019). Decolonisation of Education in African Contexts. African Renaissance, 17(2) 101-120. https://doi.org/10.31920/2516-5305/2019/V16n2a5 
Ake, C. (1982). Social science as imperialism: The theory of political development, Ibadan: Ibadan University Press.

Andreotti, V., Ahenakew, C., \& Cooper, G. (2011). Epistemological pluralism: Ethical and pedagogical challenges in higher education. Alternative: An International Journal of Indigenous Peoples, 7(1), 40-50. https://doi.org/10.1177/117718011100700104

Aoki, T. (1999) Rethinking curriculum and pedagogy. Kappa Delta Pi Record, Summer, 180-181. https://doi.org/10.1080/00228958.1999.10518454

Ashcroft, B., G. Griffiths, \& Tiffin, H. (2000). Post-colonial studies: The key concepts. London: Routledge.

Badat, S. (2016). Deciphering the meanings and explaining the South African Higher Education Student Protests of 2015-2016.

Available

at:

https://wiser.wits.ac.za/system/files/documents/Saleem\%20Badat\%20-\%20Deciphering\%20the\%20Meanings\%2 C\%20and\%20Explaining\%20the\%20South\%20African\%20Higher\%20Education\%20Student\%20Protests.pdf

[Accessed 07 February 2019].

Bathily, A., Diouf, M., \& Mbodj, M. (1995). The Senegalese student movement from its inception to1989, African Studies in Social Movements and Democracy, 368-408.

Blyden, E. (1872). The West African university. Freetown: Negro Printing Office.

CHE (Council on Higher Education). (2017). Briefly Speaking. (3)1-12. Pretoria, CHE. https://doi.org/10.5539/hes.v1n2p118

Chilisa, B. (2012). Indigenous research methodologies. Los Angeles: Sage publications.

Davids, N. (2016). On extending the truncated parameters of transformation in higher education in South Africa into a language of democratic engagement and justice. Transformation in Higher Education, 1(1). https://doi.org/10.4102/the.v1i1.7

De Wet, A., \& Simmonds, S. (2019). Human Rights Education in the South African Higher Education Context: (Im) possibilities for Human Rights Literacies. In: Roux C., Becker A. (eds) Human Rights Literacies. Interdisciplinary Studies in Human Rights, vol 2. Cham, Switzerland: Vol 2. 122-145. https://doi.org/10.1007/978-3-319-99567-0_8

DeCarvalho, J. J., \& Flórez-Flórez, J. (2014). The meeting of knowledges: A project for the decolonisation of the $\begin{array}{lllll}\text { university in Latin America. Postcolonial } & \text { Studies, } & 17(2), & 139 .\end{array}$ https://doi.org/10.1080/13688790.2014.966411

DeCuir, J. T., \& Dixson, A. D. (2004). "So When It comes out, They Aren't That Surprised That It Is There": Using Critical Race Theory as a Tool of Analysis of Race and Racism in Education." Educational Researcher, 33(5), 26-31. https://doi.org/10.3102/0013189x033005026

Dei, G. (2000). Rethinking the role of indigenous knowledges in the academy. International Journal of Inclusive Education, 4(2), 111-132. https://doi.org/10.1080/136031100284849

Deleuze, G., \& Guattari, F. (1994). What is Philosophy? H. Tomlinson and G. Burchell (Trans.). New York: Columbia University Press.

Disemelo, K. (2015). Student protests are about much more than just \#FeesMustFall. Mail \& Guardian. http://mg.co.za/author/katlego-disemelo (accessed 28 April 2016).

Fanon, F. (2001). The Wretched of the Earth. London: Penguin. https://doi.org/10.1007/978-1-137-05194-3_4

Fanon, F. (2008). Black skin, white masks. New York, NY: Grove Press. https://doi.org/10.7312/arna19364-004

Gough, N. (2011). A complexivist view of higher education: Implications for curriculum design and research on teaching and learning. Invited keynote address at the $5^{\text {th }}$ annual university teaching and learning conference. Durban: University of KwaZulu-Natal, 26-28 September.

Grosfoguel, R. (2007). The Epistemic Decolonial Turn. Cultural Studies, 21, 2-3, 211-223. https://doi.org/10.1080/09502380601162514

Grosfoguel, R. (2011). Decolonizing Post-Colonial Studies and Paradigms of Political-Economy: Transmodernity, Decolonial Thinking, and Global Coloniality. Transmodernity: Journal of Peripheral Cultural Production of the Luso-Hispanic World, 1(1), 1-37. https://doi.org/10.1080/09502380601162514 
Grumet, M. R. (1981). Restitution and reconstruction of educational experience: An autobiographical method for curriculum theory. In Rethinking curriculum studies: A radical approach, ed. M. Lawn and L. Barton, 115-130. London: Croom Helm.

Guattari, F. (2001). The three ecologies. Trans. Ian Pindar and Paul Sutton. London: The Athlone Press.

Jansen, J. (2017). "Introduction, Part II: Decolonising the University Curriculum given a Dysfunctional School System?" Journal of Education, no. 68, 3-13. https://doi.org/10.15700/saje.v38n4a1705

Laenui, Poka (Burgess, Hayden F.) (2000). "Processes of Decolonization." Reclaiming Indigenous Voice and Vision. Ed. Marie Battiste. Vancouver, BC: UBC Press, 150-160.

Le Grange, L. (2007). Integrating western and indigenous knowledge systems: The basis for effective science education in South Africa? International Review of Education, 53(5-6), 577-591. https://doi.org/10.1007/s11159-007-9056-X

Le Grange, L. (2014). Currere's active force and the Africanisation of the university curriculum. South African Journal of Higher Education, 28(4), 1284-1294. https://doi.org/10.1007/978-3-030-01352-3_13

Le Grange, L. (2016). Currere's active force and the concept of Ubuntu. Keynote address at the triennial Le Grange Decolonising the university curriculum12th conference of the International Association for the Advancement of Curriculum Studies (IAACS). The University of Ottawa. 26-30 May.

Le Grange, L. (2018). Decolonising, Africanising, indigenising, and internationalising curriculum studies: Opportunities to (re)imagine the field, Journal of Education, (74), 4-18. https://doi.org/10.17159/2520-9868/i74a01

Leibowitz, B. (2012). Introduction: Reflections on higher education and the public good. In Leibowitz, B., ed, Higher education for the public good. Views from the south. Stellenbosch: SUN MeDIA. pp. xvii-xxvii. https://doi.org/10.18820/9781928357056/00

Luckett, K. (2016). Curriculum contestation in a post-colonial context: A view from the South. Teaching in Higher Education, 21(4), 415-428. https://doi.org/10.1080/13562517.2016.1155547

Mahabeer, P. (2018). Curriculum decision-makers on decolonising the teacher education curriculum, South African Journal of Education, 38(4), 1-13. https://doi.org/10.15700/saje.v38n4a1705

Maldonado-Torres, N. (2006). Cesaire's Gift and the Decolonial Turn. Radical Philosophy Review, 9, 2, 111-138. https://doi.org/10.5840/radphilrev20069217

Maldonado-Torres, N. (2007). On the Coloniality of Being: Contributions to the development of a concept. Cultural Studies, 21(2-3), 240-270. https://doi.org/10.1080/09502380601162548

Mama, A. (2015). Decolonising knowledges 101: In the Masters' House. RMF seminars, https://www.youtube.com/watch?v=pXoisspygxU\&feature=share Date of access: 07 May 2016

Mamdani, M. (1990). The intelligentsia, the state and social movements: Some reflections on experiences in Africa. Dakar: CODESRIA.

Mbembe, A (2016). Decolonising the university: New directions. Arts \& Humanities in Higher Education, 15(1), 29-45. https://doi.org/10.1177/1474022215618513.

Mbembe, A. (2015). Decolonizing Knowledge and the question of the archive, public lecture, University of the Witwatersrand. https://wiser.wits.ac.za/system/files/Achille\%20Mb embe $\% 20$ $\%$ 20Decolonizing\%20Knowledge\%20and\%20the \%20Question\%20of\%20the\%20Archive.pdf Date of access: 30 November 2018.

McCoy, D. L., \& Rodricks, D. J. (2015). “Critical Race Theory in Higher Education: 20 Years of Theoretical Work and Research Innovations.” ASHE Higher Education Report, 41(3), 1-117. https://doi.org/10.1002/aehe.20021

McKaiser, E. (2016). Epistemic injustices: The dark side of academic freedom. IOL News, 2 June. https://www.iol.co.za/news/epistemic-injusticesthe-dark-side-of-academic-freedom-2029747 Date of access: 22 April 2018.

Mgqwashu, E. (2016). Universities can't decolonise the curriculum without defining it first. https://www.theconversation.com/universities-can't-decolonise-the-curriculum-without-defining-it-first-63948 Date of Access: 17 August 2019. 
Mheta, G., Lungu, B. N., \& Govender, T. (2018). Decolonisation of the curriculum: A case study of the Durban University of Technology in South Africa [Special issue]. South African Journal of Education, 38(4): Art. \#1635, 7 pages. https://doi.org/10.15700/saje.v38n4a1635

Mignolo, W. D. (2011). The Darker Side of Western Modernity: Global Futures, Decolonial Options. Durham \& London: Duke University Press. https://doi.org/10.1515/9780822394501

Murris, K. (2016). \#RHODES MUST FALL: a posthumanist orientation to decolonising higher education institutions, South African Journal of Higher Education, 30(3), 274-294. https://doi.org/10.20853/30-3-653

Mustapha, A. (1995). Society and the social sciences in northern Nigeria, 1962-94: A case study of Ahmadu Bello University. CODESRIA Bulletin, 2, 12-16.

Nabudere, D. (2011). Afrikology, philosophy and wholeness: An epistemology. Pretoria: Africa Institute of South Africa.

Naicker, C. (2016). A panel discussion, a conference on decolonizing the academy, University of Edinburgh, https://www.youtube.com/watch?v=laDIAAwZ6-A Date of access: 31 January 2018.

National Planning Commission. (2011). National development plan: Vision for 2030. http://www.policyresearch.limpopo.gov.za/bitstream/handle/123456789/941/NDP\%20Vision\%202030.pdf?se quence=1 Date of access: 12 December 2017.

Ndlovu-Gatsheni, S. J. (2013). Why decoloniality in the 21st century? The Thinker, 48, 10-15. https://doi.org/10.15700/saje.v38n4editorial

Ndlovu-Gatsheni, S. G., \& Omanga, D. (2020). Decolonisation, Decoloniality and the Future of African Studies. https://oxfamblogs.org/fp2p/decolonization-decoloniality-and-the-future-of-african-studies/ (retrieved 25 July 2020).

Ngugi, Wa Thiong'o. (1986). Decolonising the mind: The politics of language in African literature, Nairobi: East African Education Publishers Ltd.

Nkrumah, K. (1974). Consciencism: philosophy and ideology for decolonisation. London: Heinemann.

Nzimande, B. (2015). Speech by Minister Blade Nzimande at the Higher Education Summit held at theInkosi Albert Luthuli

ICC, Durban. http://www.gov.za/speeches/speech-minister-be-nzimande-higher-education-summit-held-inkosi-albert-1 uthuli-icc-durban (accessed 12 May 2016).

Odora-Hoppers, C., \& Richards. H. (2011). Rethinking thinking: Modernity's 'other' and the transformation of the university. Pretoria: Unisa Press.

Olssen, M., J. Codd \& A. O’Neill. (2004). Education policy: Globalization, citizenship and democracy. London: Sage publications.

Peters, M. (2007). Knowledge economy, development and the future of higher education. Rotterdam/Tapei: Sense publishers. https://doi.org/10.1163/9789087903497

Pilane, P. (2016). Three reasons why \#FeesMustFall protests will continue. Mail \&Guardian. http://mg.co.za/article/2016-01-13-three-reasons-why-feesmustfall-protests-will-continue (accessed 28 April 2016).

Pillay, S. (2015). Decolonizing the university. Azania House, Bremner Building, University of Cape Town, http://africasacountry.com/decolonizing-the-university/ Date of access: 27 March 2016

Pinar, W. F. (2011). The character of curriculum studies: Bildung, currere and the recurring question of the subject. New York: Palgrave MacMillan. https://doi.org/10.1057/9781137015839_9

Pinar, W. F. (1975). Curriculum Theorizing: The Reconceptualists, California: McCutchan.

Pinar, W. F. (2004). What Is Curriculum Theory? New Jersey: Lawrence Erlbaum Associates.

Pindar, I., \& Sutton. P. (2001). Translators' introduction. In The three ecologies, ed. F. Guattari. Translated by I. Pindar and P. Sutton. London: The Athlone Press.

Quijano, A. (2007). Coloniality and Modernity/rationality. Cultural Studies, 21, 2-3, 168-178. https://doi.org/10.1080/09502380601164353 
Ramrathan, L. (2016). Beyond counting the numbers: Shifting higher education transformation into curriculum spaces. Transformation in Higher Education, 1(1), 1-8. https://doi.org/10.4102/the.v1i1.6

Roithmayer, D. (1999). "Introduction to critical race theory in educational research and praxis". In Race is... race isn't: Critical race theory and qualitative studies. In: Parker, L., Deyhle, D. \& Villenas. J., eds. S. 1-6. Boulder, CO: Westview Press. pp. S1-6. https://doi.org/10.4324/9780429503504-1

Santos, B. (2014). Epistemologies of the South: Justice against epistemicide. Boulder: Paradigm Publishers. https://doi.org/10.4324/9781315634876

Sayed, Y., Motala, S., \& Hoffman, N. (2017). Decolonising initial teacher education in South African universities: More than an event, Journal of Education, 68, 59-87.

Shay, S. (2016). Decolonise more than just curriculum content - change the structure, too. The Conversation. Retrieved

from https://theconversation.com/decolonisemore-than-just-curriculum-content-change-thestructure-too-44480.

Shivji, I. (1993). Intellectuals at the hill: Essays and talks, 1969-1993. Dar es Salaam: Dar es Salaam University Press.

Smith, L. (1999). Decolonising methodologies: Research and indigenous peoples. London: Zed Books.

Taylor, F. W. (1911). The principles of scientific management. New York: Harper \& Brothers.

Tuck, E., \& Yang, K.W. (2012). Decolonization is not a metaphor. Decolonization: Indigeneity, Education \& Society, $1(1), 1-40$

Turnbull, D. (1997). Reframing science and other local knowledge traditions. Futures, 29(6), 551-562. https://doi.org/10.1016/S0016-3287 (97)00030-X

Venter, P. (2018). Postkoloniale teologie en die sending: Uitdagings en bedreigings. Tydskrif vir Geesteswetenskappe, 58(1), 96-108. https://doi.org/10.17159/2224-7912/2018/v58n1a6

Wallin, J. J. (2010). A Deleuzian approach to the curriculum: Essays on a pedagogical life. New York: Palgrave Macmillan. https://doi.org/10.1057/9780230115286

Zembylas, M. (2018). The Entanglement of Decolonial and Posthuman Perspectives: Tensions and Implications for Curriculum and Pedagogy in Higher Education. Parallax, 24, 3, 254-267. https://doi.org/10.1080/13534645.2018.1496577

\section{Copyrights}

Copyright for this article is retained by the author(s), with first publication rights granted to the journal.

This is an open-access article distributed under the terms and conditions of the Creative Commons Attribution license (http://creativecommons.org/licenses/by/4.0/). 